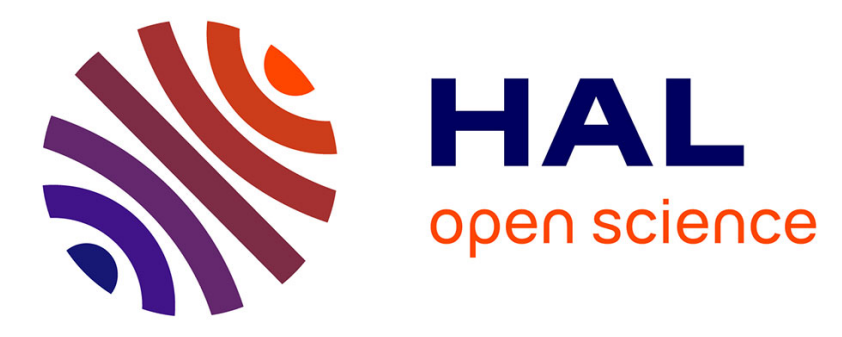

\title{
Safety and effectiveness of cervical vertebroplasty: report of a large cohort and systematic review
}

Frédéric Clarençon, Robert Fahed, Évelyne Cormier, Idriss Haffaf, Jean-Philippe Spano, Eimad Shotar, Kévin Premat, Raphael Bonaccorsi, Vincent Degos, Jacques Chiras

\section{To cite this version:}

Frédéric Clarençon, Robert Fahed, Évelyne Cormier, Idriss Haffaf, Jean-Philippe Spano, et al.. Safety and effectiveness of cervical vertebroplasty: report of a large cohort and systematic review. European Radiology, 2020, 30 (3), pp.1571-1583. 10.1007/s00330-019-06525-w . hal-02874016

\section{HAL Id: hal-02874016 https: / hal.sorbonne-universite.fr/hal-02874016}

Submitted on 26 Jun 2020

HAL is a multi-disciplinary open access archive for the deposit and dissemination of scientific research documents, whether they are published or not. The documents may come from teaching and research institutions in France or abroad, or from public or private research centers.
L'archive ouverte pluridisciplinaire HAL, est destinée au dépôt et à la diffusion de documents scientifiques de niveau recherche, publiés ou non, émanant des établissements d'enseignement et de recherche français ou étrangers, des laboratoires publics ou privés. 


\title{
Safety and Effectiveness of Cervical Vertebroplasty: Report of a Large Cohort and Systematic Review
}

\author{
Frédéric Clarençon, Robert Fahed, Evelyne Cormier, Idriss \\ Haffaf, Jean-Philippe Spano, Eimad Shotar, Kévin Premat, \\ Raphaël Bonccorsi, Vincent Degos et Jacques Chiras
}

\begin{abstract}
:
Purpose

To evaluate retrospectively safety and effectiveness of cervical vertebroplasty (cVP) based on a single centre large cohort.

\section{Materials and Methods}

All cVP performed at single centre from January 2001 to October 2014 were included and reviewed.

Procedure-related complications (minor and major) were systematically recorded.

Effectiveness in terms of analgesia was evaluated using a semi-quantitative grading scale at one-month follow-up.

Risk factors for the occurrence of a procedure-related complication or cement leakage, as well as factors influencing pain relief at one-month follow-up were evaluated using a multivariate analysis.
\end{abstract}

\section{Results}

One hundred and forty cVP procedures (176 vertebrae) were performed in 130 consecutive patients ( 88 female, 42 male; mean age $=56 y$ ) during the inclusion period.

Among the treated lesions, $80 \%$ were bone metastases (mostly from breast cancer), $8 \%$ were related to haematological malignancies and $12 \%$ were nonmalignant lesions.

One fatal complication $(0.7 \%)$ was related to cement migration in the vertebrobasilar system. Three cervical hematomas were recorded, one of them requiring prolonged oral intubation. Overall rate of major complications was $1.5 \%$.

At one month, pain reduction was observed in $76 \%$ of the cases.

Additional surgical fixation was required in $6.1 \%$ of the cases.

cVP of more than one vertebra during the same session was an independent risk factor for procedure-related complication.

\section{Conclusion}

Cervical vertebroplasty is a safe technique with an acceptable major complication rate. Its effectiveness in terms of pain relief is good at mid-term follow-up. 


\section{Key words:}

Vertebroplasty, spine, analgesia

\section{Abbreviations and acronyms:}

ABC: aneurysmal bone cyst; cVP: cervical vertebroplasty; IV: intravenous; PMMA: polymethyl methacrylate; PVP: percutaneous vertebroplasty; VP: vertebroplasty; VA: vertebral artery.

\section{Key Points:}

1. Cervical vertebroplasty (cVP) is a safe procedure with a low rate of major complications $(1.5 \%)$

2. cVP provides pain relief in $76 \%$ of the cases

3 . Additional fixation surgery is rarely required after cVP (6.1\% of the cases) 


\section{Introduction:}

Percutaneous vertebroplasty (PVP) has been first described in 1987 for the treatment of a spinal aggressive haemangioma [1]. Since then, the indications of PVP have expanded and now, this technique is used for the treatment of traumatic [2], porotic [3] or metastatic [4] lesions, mainly of the thoracic and lumbar spine. Cervical vertebroplasty (cVP) has been described more recently and appears more challenging to perform due to specific technical difficulties. Indeed, the cervical vertebrae are close to critical structures such as internal carotid and vertebral arteries, phrenic nerve and trachea. Additionally, potential bone cement migration posteriorly into the spinal canal during cVP may lead to devastating sequelae like tetraparesis or even death in case of cervical spinal cord compression. Only limited data, mainly short case series [5-20], are available in the literature on the safety and effectiveness of cVP.

The purpose of this study was to report a single centre experience in cVP regarding its safety and effectiveness in a large cohort, and to evaluate the risk factors of severe complications during cVP. 


\section{Materials and Methods:}

\section{Design of the study}

Monocentric, retrospective, observational study.

\section{Patient selection}

All consecutive cVP procedures performed at a single Institution from January 2001 to October 2014 were retrospectively reviewed.

Inclusion criteria were as follows: patient $\geq 18$ year of age with a painful and/or unstable lesion of the cervical spine requiring a VP.

Patients were considered not eligible for a cVP when they presented one or more of the following exclusion criteria: pregnancy, coagulation disorder, on-going infectious disease, known allergy to polymethyl methacrylate (PMMA) or contraindication to general anesthesia.

The information was collected retrospectively in the medical and computed patients' medical charts by two interventional neuroradiologists and the data were secondarily double-checked by an experienced clinical manager.

The database was created using an Excel worksheet. All patients' names were anonymized.

\section{Study endpoints}

The primary endpoint of the study was to evaluate the safety of cVP.

Secondary endpoints were clinical effectiveness in terms of pain relief and adequate bone stabilization, evaluated with a surrogate marker being the absence of need for an additional surgical fixation. 


\section{Cervical lesions' characteristics}

Pre-cVP imaging work-ups (CT and/or MRI) were reviewed by 2 neuroradiologists. The nature of the lesions was evaluated and divided into: osteolytic, osteoblastic or mixed. The presence of a posterior wall disruption, as well as the presence of a contact of the target lesion with the transverse foramen were evaluated on pretreatment imaging.

\section{cVP procedures:}

Most of the procedures were performed with bi-plane fluoroscopic guidance under general anaesthesia. Patient was positioned in the supine position with the head in extension. In strict aseptic conditions, with surgical disinfection of the neck, one 11G $100 \mathrm{~mm}$-length bone needle (Thiebaud) was used for each cervical vertebra treated. In most cases (75\%), a right anterolateral approach was used. None of the approaches required any surgical incision; all procedures were performed in a percutaneous fashion (or through the pharyngeal mucosa for transoral vertebroplasties). Cervical carotid artery was palpated and manually pulled laterally with the operator's fingers used as a hook. Then, the bone needle was inserted percutaneously via an antero-lateral approach between the cervical carotid artery and the trachea, under fluoroscopic guidance, for each treated level (Fig. 1). In patients treated for C1 lateral mass lesions, a transoral route was used, as described in a previous paper (3.3\% of the cases) [21]. In $5.3 \%$ of the cases, a non-compliant protection balloon navigated in the vertebral artery (VA) ipsilateral to the lesion from a guiding catheter positioned in the VA, via a femoral access. This balloon protection was temporarily inflated under full IV 
anticoagulation and aimed to prevent cement retrograde migration in the VA ipsilateral to the lesion via the arterial feeders.

Cement used was PMMA high-viscosity bone cement: Biomet V Cement (Biomet) in the majority of the cases. In $26.24 \%$ of the cases, Methylmetacrylate (from 2001 to 2004) was used, in one case (0.7\%) Simplex P bone cement (Stryker) was used; in another case $(0.7 \%)$, Osteopal V cement (Heraeus Medical) was used. Cement injection was performed until satisfactory filling of the lesion with the minimum amount of perivertebral cement leakage (Fig. 2). At the beginning of the procedure $1 \mathrm{~g}$ intravenous (IV) cefazolin (or other broad spectrum antibiotic) was also administered in order to minimize any risk of infection.

\section{Complications:}

Periprocedural and delayed complications were systematically assessed. Complications were divided into two categories, adapted from previously published guidelines [22]: major complications (procedure related-death, cervical hematoma requiring surgery or prolonged intubation, permanent neurological deficit, decompensation of a comorbidity) and minor complications (transient pain worsening, minor local hematoma, reversible nerve root compression).

\section{Clinical follow-up:}

Clinical follow-up was performed one month after the cVP. Pain relief was evaluated using a semi-quantitative scale previously used in several studies [21; 23]: 0: major pain worsening, 1: mild pain worsening, 2: stable pain, 3: mild 
improvement and 4: marked improvement. In case of persistent or worsened pain, a control imaging (CT scan, MRI and/or PET-CT) was performed to rule out local recurrence or new adjacent lesion.

Additional stabilization surgery during the follow-up was systematically recorded. The absence of need for additional surgery was used as a surrogate of satisfactory bone stabilization with cVP alone.

\section{Imaging follow-up:}

All patients underwent non-enhanced CT with bone windowing just after the cVP. Perivertebral cement leakages (anterior or lateral) were evaluated on postoperative CT, as well as posterior (i.e.: epidural and/or spinal canal) leakages.

In case of complication (hematoma, neurological deficit), CT and/or MRI were performed depending on symptoms.

At follow-up, imaging (CT and/or MRI) was performed if patient did not experience pain relief or if the patient had a pain recurrence.

\section{Systematic review of the literature}

A systematic review of the literature on safety and effectiveness on cVP was performed according to the PRISMA (Preferred Reporting Items for Systematic Reviews and Meta-Analyses) guidelines [24]. The different studies were analysed using combinations of terms in title, abstract, keywords and free text, until 1st August 2019. The search was performed on MEDLINE via PubMed, Embase via 
Ovid and Cochrane central database via CENTRAL with advanced search builder. The following terms and synonyms were used: cervical, vertebroplasty, atlas, axis, C1 and C2. Additionally, references from the publications obtained were checked to add relevant studies. This systematic review of the literature was performed by two investigators (FC and KP).

Animal studies, case reports, surgical series, non-relevant studies and nonEnglish written series were then excluded. Only the studies reporting at least 5 cervical vertebroplasties were kept in this systematic review (Fig. 3). Risk of bias was evaluated by both reviewers using the Newcastle-Ottawa Quality Assessment Form for Cohort and Case-control Studies [25].

\section{Statistical analysis:}

The following characteristics were evaluated in order to correlate their influence on the complication rate, as well as on the pain relief: patient's age, sex, lesion type (metastasis, haematological malignancy, non-malignant tumor), imaging appearance (osteolytic, sclerotic or mixed lesion), a posterior wall disruption and the contact of the target lesion with the transverse foramen. Chi-square or Fisher's exact tests were used for categorical variables and Student's t test or Wilcoxon test for continuous variables, depending on the data distribution. Multivariate analysis (multivariate regression) evaluated the influence of the above-mentioned criteria on complication occurrence (minor or major), the risk of cement leakage, then on pain relief. All tests were calculated using Stata software (Stata/IC 13.1 for Mac; StataCorp LP,); p values less than 0.05 were considered statistically significant. 


\section{Ethical statement:}

All patients had a pre-treatment consultation and gave oral consent for the intervention.

The need for patients' informed consent for retrospective analyses of records and imaging data was waived by the local Institutional Review Board. This work adheres to the World Medical Association Declaration of Helsinki. 


\section{Results:}

\section{Patients' demographics and cervical lesions' characteristics}

\section{Patients' demographics are summarized in Table 1.}

From January 2001 to October 2014, 140 cVP procedures (176 vertebrae) were performed in 130 consecutive patients ( 88 female, 42 male; mean age $=56 \pm 15$ years, range: 16-91). Nine patients had already been included in a previous case series focused on C2 published by the authors [9]. Three other patients had also already been included in a previous study focused of cVP in patients with multiple myeloma [10]. Two other patients of the cohort have already been reported in an article describing the early experience of the authors in transoral VP of the lateral mass of C1 [21]. Finally, a last patient of the study cohort, a very rare case of glioblastoma metastasis treated by VP, has been reported as a case report [26].

One hundred and forty-one out of the 176 lesions (80\%) were cervical spine metastases from various cancers (see Table 1); 14/176 (8\%) were haematological malignancies (13 from multiple myeloma [7.5\%] and 1 from lymphoma [0.5\%]) and $12 \% \quad(21 / 176)$ were non-malignant lesions (hemangiomas, aneurysmal bone cyst, ...) (Fig. 4).

Average number of cervical vertebrae treated per procedure was $1.3 \pm 0.6$ (range: $1-4)$.

Pre-cVP imaging work-up was available in 119/130 patients (91.5\%) for 125/176 (73.5\%) treated vertebrae (a summary of lesions' characteristics is displayed in Table 1). Among the treated lesions, 93.4\% (117/125) were osteolytic; $5.6 \%(8 / 125)$ were mixed lesions and $0.8 \%(1 / 125)$ were osteoblastic. The later patient with an osteoblastic lesion was treated by cVP 
because the lesion was responsible for severe cervical pain. Most frequently involved vertebrae were $\mathrm{C} 7$, followed by $\mathrm{C} 2$ (see Fig. 5 for the distribution of the lesions along the cervical spine). The lesion's extension to the posterior wall of the treated vertebrae could be analysed in 98 cases $(78.4 \%)$; a posterior wall disruption was observed in 17/98 (17.3\%) of the cases. Additionally, contact of the target lesion with the transverse foramen was seen in $26.5 \%$ of the cases (26/98).

In $10.8 \%(14 / 130)$ of the cases, surgical fixation has already been performed before the cVP.

The mean volume of bone cement injected in each vertebral body during the procedure was $2.47 \pm 0.88 \mathrm{ml}$.

Average dose-surface product (DSP) was $2280.6 \pm 3305.2 \mu \mathrm{Gy} . \mathrm{m}^{2}$ per procedure.

\section{Procedure-related complications}

A major procedure-related complication was recorded in 2 cases $(1.5 \%)$. The first major complication consisted in a fatal migration of bone cement in the vertebrobasilar system. This complication occurred in a 58-year-old female who presented a C6 metastasis from a breast cancer. The patient already underwent a cVP but with an incomplete filling of the lesion. It was thus decided to perform a second session of cVP. During the injection, uncontrolled cement migration in the vertebrobasilar system occurred, leading to massive ischemic infarct and death. Of note, this lesion was located close the transverse canal.

The second major complication consisted in a severe cervical hematoma that required prolonged oral intubation due to airway compression. 
Additionally, two minor cervical hematomas were recorded, which did not require surgical treatment, blood transfusion or prolonged intubation.

One case of asymptomatic occlusion of a vertebral artery harbouring an underlying stenosis of the V3 segment occurred, in a patient treated for a C2 lesion for which a balloon protection was navigated in the V3 segment.

The overall cement leakage rate was $61 \%$ (85/140 cases). Anterior cement migration (along the entry point of the bone needle) was seen in $46.5 \%$ $(65 / 140)$. All patients with anterior cement migration along the entry point of the bone needle (46.5\%) were asymptomatic at long-term follow-up. Posterior cement migration in the anterior epidural plexus was seen in $11.3 \%$ of the cases. However no spinal cord compression was recorded in these cases. In 3.5\%, a lateral cement leakage in the intervertebral foramen was depicted. One of these leakages was responsible for cement migration in the vertebro-basilar system (described above). None of these lateral migrations was responsible for any nerve root compression.

No late complication was recorded.

Univariate analysis did not find any predictor for either procedure-related complication or bone cement leakage. Multivariate analysis showed an increased risk of cement leakage in tumour lesions (osteolytic or not) $(\mathrm{P}=0.016)$ and an increased risk of major complication in patients treated for $\geq 2$ lesions during the same cVP session $(\mathrm{P}=0.015)$.

\section{One-month clinical outcome}

One-month clinical evaluation was available in 75/130 patients (58\%). Pain improvement was observed at one-month follow-up in 76\% (57/75) of the cases 
(major improvement: 53.3\% [40/75], minor improvement: 22.6\% [17/75]). Pain was stable in $9.3 \%(7 / 75)$ of the cases. In the remaining $14.7 \%(11 / 75)$ of the patients, pain increased (minor increase: 5.3\% [4/75]; major increase: $9.3 \%$ [7/75]). Among the different tested risk factors, univariate analysis showed only a negative influence of a posterior wall disruption on pain relief $(\mathrm{P}<0.05)$. However, on multivariate analysis, neither age, sex, underlying disease, posterior wall disruption, nor lytic/blastic characteristic of the lesion had any independent influence on pain relief.

\section{Bone stabilization}

Additional surgical fixation was required in $6.1 \%$ (8/130 patients) of the cases during the follow-up period. Such additional surgical fixation was performed when pain was not relieved by the cVP and/or it was estimated that the bone stabilization provided by the cVP was insufficient. No secondary fracture was depicted in this series during the follow-up period.

\section{Review of the literature}

The systematic review of the literature retrieved 16 series on cVP including from 5 to 62 patients (average: 13.9) [5-20]. According to the Newcastle-Ottawa grading scale [25], the risk of biases was fair for all the 16 series included in the systematic review. Procedure-related death was recorded in 0 to $9 \%$ of the cases. Overall complication rate ranged from 0 to 55.6\%. Major complications were reported ranging from 0 to $18 \%$, minor complications from 0 to $55.6 \%$. Pain 
relief was reported ranging from 80 to 100\%. Local progression after cVP has been reported in one case $(25 \%)$ in a series of 4 patients treated for multiple myeloma [10]. Spinal cord compression due to insufficient spine stability provided by the cVP was reported in one case (11\%) in a series involving 9 patients with cervical metastases [6]. The need for additional surgical fixation in addition to cVP was reported only in one series [14], in $28.6 \%$ of the cases (odontoid screw fixation). 


\section{Discussion:}

This large cohort shows the safety of cVP, with an acceptable major complication rate $(1.5 \%)$. Interestingly, all these major complications $(n=2)$ occurred in the early experience of the authors, between 2001 and 2004 .

Pain relief (either partial or complete) was obtained in $76 \%$ of the cases in this series. Additional surgery was required in only $6.1 \%$ of the cases.

Only treatment of several cervical vertebrae during the same session was depicted as a risk factor for procedure-related complication by the multivariate analysis.

Cervical spine metastases represent 8 to $15 \%$ of all spine metastases [27]. The treatment of cervical metastases is either systemic (chemotherapy, hormonotherapy) or focused (radiotherapy, open surgery or percutaneous interventions). Among these focal treatments, only surgery and percutaneous vertebroplasty/kyphoplasty provide bone stabilization; radiotherapy may help in obtaining a debulking of the lesion and potentially pain relief, especially in case of epidural extension, but not bone stabilization. Surgical treatment includes vertebrectomy with vertebral body replacement, spinal decompression surgery, and ventral or dorsal spondylodesis. The main limitations for open surgery are patients with poor clinical status, a short life expectancy, patients treated by anti-angiogenic agents or previously treated by radiotherapy. Hypervascularized lesions may also be a limitation for open surgery, due to the risk of major intraprocedural bleeding.

The largest series on cVP published to date included 62 patients with 70 treated vertebrae [8]. It is noteworthy that only one series evaluating the safety and 
effectiveness of percutaneous balloon kyphoplasty in cervical tumor lesions has been published so far [7].

\section{Complications:}

Several complications may occur during VP in general [28]. The main complications are perivertebral venous leakages [29], intervertebral disk leakages [30], pulmonary/cardiac cement emboli [29; 31], spinal canal or intervertebral foramen cements leakages. Although very rare, neurological complications have also been described, like paraplegia due to cement migration in a radiculomedullary artery [32] or intracranial artery cement emboli in a patient with patent foramen ovale [33; 34]. In cVP, only scant complications have been reported in the literature. Procedure-related deaths have been reported ranging from 0 to $9 \%$ [5-20]. One pulmonary decompensation secondary to cVP has been reported by Sebaaly et al [15] in their cases series, leading to a $9 \%$ death rate. In the present series, one procedure-related death $(0.7 \%$ rate $)$ was recorded due to cement migration in the vertebrobasilar system. Another similar complication has been reported in cVP as a case report by Beji et al [35]: they described cement migration in the V3 segment of the vertebral artery during a transoral vertebroplasty for a C2 lesion in a patient with multiple myeloma. Fortunately, the cement did not migrate in the basilar artery and since the patient had a large contralateral vertebral artery, this complication remained asymptomatic.

To reduce the risk of such vertebrobasilar vascular cement migration, especially in hypervascularized lesions, intralesional angiography though the bone needle 
may be a potential option. It may help to depict intralesional arterio-arterial anastomoses. However, one should keep in mind that such intralesional angiography may help in predicting cement vascular leakage in only less than $1 / 3$ of the cases [36]. Also, a second puncture and injection of cement in a previous VP treated vertebra may provide additional risk of cement leakage due to the presence of a previous radiopaque material in the vertebral body.

Major complication rate has been reported ranging from 0 to $18 \%$ of the cases [5-20]. Neurological complications are the most feared complications. The authors already reported, in a previous series on C2 cVP [9], a case of ischemic stroke in the vertebrobasilar system secondary to a spasm of the vertebral artery. Minor complications consisting in occipital neuralgia [9] and mild odynophagia [6;11; 13] have also been reported (Table 2).

Additionally, patients treated for $\geq 2$ lesions during the same cVP session had an increased risk of procedure-related complication $(P=0.015)$. This can be explained by the duration of such procedures, with multiple bone needles positioning, which could increase the complication risks, especially for cervical hematomas.

In this study, cement leakage was observed in $61 \%$ of the cases, which is higher than the cement leakage rate in $\mathrm{cVP}$ reported in a recent meta-analysis on the topic (16\%) [37]. As observed herein, most of the cement leakages reported were located in the precervical space, along the entry point of the bone needle. These precervical cement leakages (observed in $46.8 \%$ of the cases in this series) may be responsible for a transient dysphagia. However, the authors were not able to report the rate of such minor complications, since it was not systematically reported in the medical chart. 
Interestingly, the statistical analysis showed an increased risk of cement leakage in tumour lesions (osteolytic or not) $(\mathrm{P}=0.016)$, which could be explain by a more unpredictable filling of these lesions during cement injection, compared to hemangiomas for instance.

\section{Pain relief:}

Pain relief was obtained in $76 \%$ of the cases in this series. In $10.5 \%$ of the cases, pain was stable. In the literature, pain relief is reported varying from 80 to $100 \%$ [5-20] (Table 2). The pain relief rate in this series was slightly lower than the ones reported in the literature, which may be explained by the fact that very challenging lesions were included in this series $(17.3 \%$ of the lesions presented a posterior wall disruption and $26.5 \%$ had a contact with the transverse canal). As for other vertebrae (i.e.: thoracic and lumbar), pain relief in cervical VP is obtained via the stabilization of the lesion and by the tumor destruction related to exothermic reaction during the bone cement polymerization [38]. Incomplete pain relief after cVP may be related to insufficient bone stabilization due to incomplete filling of the lesion by the PMMA cement or to major extension of the lesion to the vertebra's posterior arch. In such cases, complementary surgical intervention may be necessary.

\section{Stabilization:}

In this study, only $6.1 \%$ of the patients required an additional fixation surgery. The need for additional fixation surgery was considered as a surrogate marker of bone stabilization. Thus, in more than $90 \%$ of the patients, the stabilization 
provided by the cVP alone was sufficient. No new fracture or worsening of a vertebral collapse was observed on the treated cervical vertebrae in this series. In 2 case series [6; 10], a case of local progression was recorded; one being responsible for spine instability [10]; the second one revealed by tetraplegia leading to death [6].

Moreover, even if not observed in this series and not reported in the literature, secondary fracture may occur in case of incomplete lesion filling, especially for C2 lesions involving the dens.

\section{Specific considerations according to the treated level:}

The most frequently treated cervical levels in this series were C2 and C7 (22.7 and 23.3\%, respectively). In this study, all C2 lesions were treated using an anterolateral approach. In this specific location, the needle course should be ascendant. It may allow filling both the dens of $\mathrm{C} 2$ and the $\mathrm{C} 2$ vertebral body (Fig. 6). The authors thus think that this route is better than the previously reported transoral route for C2 lesions [5], because it is easier to reach and it allows a better filling of the $\mathrm{C} 2$ lesions. Interestingly, trans-C2-C3 disk route has also been reported in challenging lesions of C2 [39].

C6 and C7 cVP may also be difficult to perform in patients with a short neck and prominent shoulders. To overcome this limitation, pulling the patient's arm downward may help to extricate the lower cervical vertebrae. Another possibility is to put the patient's arms in the "swimmer" position, with one arm up and the other one down. Another option may be to tilt the C-arm in a craniocaudal fashion in lateral projection. 
Finally, lesions of the lateral mass of $\mathrm{C} 1$ were treated in this series via a transoral route according to a technique previously described [21]. This route was chosen because it reduces the risk of vertebral artery injury.

\section{Limitations of the study:}

The main limitation of this study is its retrospective and monocentric nature. This design may expose to biases and hampers the generalization of these results. Moreover, this study was weakened by a significant number of patients who were lost during the follow-up (42\%). Additionally, pretreatment VAS evaluation was not available in numerous patients. Thus, the authors used a semi-quantitative grading scale to evaluate pain relief. However, the authors acknowledge that this semi-quantitative scale is less precise than comparison between pre and post-treatment VAS. The fact that one-month clinical evaluation was performed by the operator who did the cVP, with no standardized questionnaire, may also carry a bias.

Finally, this series lacks a comparison with the standard, which is instrumented orthopaedic surgery. 


\section{Conclusion}

Cervical vertebroplasty is an effective technique in terms of pain relief and bone stabilization for the management of cervical lesions, with an acceptable rate of major complications. Physicians should take care of bone cement migration laterally, which may be responsible for vertebrobasilar stroke. The use of adequate protocols (bi-plan fluoroscopic guidance, general anaesthesia, reduced number of cervical vertebrae treated during the same session) may help in reducing further the risk for complication. 


\section{References:}

1 Galibert P, Deramond H, Rosat P, Le Gars D (1987) [Preliminary note on the treatment of vertebral angioma by percutaneous acrylic vertebroplasty]. Neurochirurgie 33:166-168

2 Ahlhelm F, Omidi R (2016) [Kyphoplasty and vertebroplasty for spinal trauma]. Radiologe 56:691-697

3 Clark W, Bird P, Gonski P et al (2016) Safety and efficacy of vertebroplasty for acute painful osteoporotic fractures (VAPOUR): a multicentre, randomised, double-blind, placebo-controlled trial. Lancet 388:14081416

4 Weill A, Chiras J, Simon JM, Rose M, Sola-Martinez T, Enkaoua E (1996) Spinal metastases: indications for and results of percutaneous injection of acrylic surgical cement. Radiology 199:241-247

5 Anselmetti GC, Manca A, Montemurro F et al (2012) Vertebroplasty using transoral approach in painful malignant involvement of the second cervical vertebra (C2): a single-institution series of 25 patients. Pain Physician 15:35-42

6 Bao L, Jia P, Li J et al (2017) Percutaneous Vertebroplasty Relieves Pain in Cervical Spine Metastases. Pain Res Manag 2017:3926318

7 Blondel B, Adetchessi T, Demakakos J, Pech-Gourg G, Dufour H, Fuentes S (2012) Anterolateral kyphoplasty in the management of cervical spinal metastasis. Orthop Traumatol Surg Res 98:341-345

8 Masala S, Anselmetti GC, Muto M, Mammucari M, Volpi T, Simonetti G (2011) Percutaneous vertebroplasty relieves pain in metastatic cervical fractures. Clin Orthop Relat Res 469:715-722

9 Mont'Alverne F, Vallee JN, Cormier E et al (2005) Percutaneous vertebroplasty for metastatic involvement of the axis. AJNR Am J Neuroradiol 26:1641-1645

10 Mont'Alverne F, Vallee JN, Guillevin R et al (2009) Percutaneous vertebroplasty for multiple myeloma of the cervical spine. Neuroradiology 51:237-242

11 Sun G, Jin P, Li M et al (2010) Percutaneous vertebroplasty for treatment of osteolytic metastases of the $\mathrm{C} 2$ vertebral body using anterolateral and posterolateral approach. Technol Cancer Res Treat 9:417-422

12 Pflugmacher R, Schleicher P, Schroder RJ, Melcher I, Klostermann CK (2006) Maintained pain reduction in five patients with multiple myeloma 12 months after treatment of the involved cervical vertebrae with vertebroplasty. Acta Radiol 47:823-829

13 Sun G, Wang LJ, Jin P, Liu XW, Li M (2013) Vertebroplasty for treatment of osteolytic metastases at C2 using an anterolateral approach. Pain Physician 16:E427-434

14 Stangenberg M, Viezens L, Eicker SO, Mohme M, Mende KC, Dreimann M (2017) Cervical vertebroplasty for osteolytic metastases as a minimally invasive therapeutic option in oncological surgery: outcome in 14 cases. Neurosurg Focus 43:E3

15 Sebaaly A, Najjar A, Wang Z, Boubez G, Masucci L, Shedid D (2018) Anterolateral Cervical Kyphoplasty for Metastatic Cervical Spine Lesions. Asian Spine J 12:823-829 
16 Guo WH, Meng MB, You X et al (2012) CT-guided percutaneous vertebroplasty of the upper cervical spine via a translateral approach. Pain Physician 15:E733-741

17 Kordecki K, Lewszuk A, Pulawska-Stalmach M et al (2015) Vertebroplasty of cervical vertebra. Pol J Radiol 80:51-56

18 Guarnieri G, Vassallo P, Ambrosanio G et al (2010) Vertebroplasty as a Treatment for Primary Benign or Metastatic Cervical Spine Lesions: Up to One Year of Follow-up. Neuroradiol J 23:90-94

19 Jian W (2013) Symptomatic cervical vertebral hemangioma treated by percutaneous vertebroplasty. Pain Physician 16:E419-425

20 Chen L, Su IC, Ni CF, Wang ZT (2014) Percutaneous vertebroplasty performed with an 18-gauge needle for treatment of metastatic severe compression fracture of the cervical vertebral body. J Vasc Interv Radiol 25:1413-1417

21 Clarencon F, Cormier E, Pascal-Moussellard H et al (2013) Transoral approach for percutaneous vertebroplasty in the treatment of osteolytic tumor lesions of the lateral mass of the atlas: feasibility and initial experience in 2 patients. Spine (Phila Pa 1976) 38:E193-197

22 Sacks D, McClenny TE, Cardella JF, Lewis CA (2003) Society of Interventional Radiology clinical practice guidelines. J Vasc Interv Radiol 14:S199-202

23 Pereira LP, Clarencon F, Cormier E et al (2013) Safety and effectiveness of percutaneous sacroplasty: a single-centre experience in 58 consecutive patients with tumours or osteoporotic insufficient fractures treated under fluoroscopic guidance. Eur Radiol 23:2764-2772

24 http://www.prisma-statement.org

25 The Newcastle-Ottawa Scale (NOS) for Assessing the Quality of NonRandomized Studies in Meta-Analysis | Request PDF [Internet]. ResearchGate. [cited 2019 Feb 9];Available from: https://www.researchgate.net/publication/261773681 The NewcastleOttawa Scale NOS for Assessing the Quality of NonRandomized Studies in Meta-Analysis.

26 Pham CT, Clarencon F, Ganem G et al (2011) Spinal cervical metastasis from a glioblastoma multiform treated by percutaneous vertebroplasty: a case report. J Neuroradiol 38:323-325

27 Mesfin A, Buchowski JM, Gokaslan ZL, Bird JE (2015) Management of metastatic cervical spine tumors. J Am Acad Orthop Surg 23:38-46

28 Laredo JD, Hamze B (2005) Complications of percutaneous vertebroplasty and their prevention. Semin Ultrasound CT MR 26:65-80

29 Barragan-Campos HM, Vallee JN, Lo D et al (2006) Percutaneous vertebroplasty for spinal metastases: complications. Radiology 238:354362

30 Syed MI, Patel NA, Jan S, Harron MS, Morar K, Shaikh A (2005) Intradiskal extravasation with low-volume cement filling in percutaneous vertebroplasty. AJNR Am J Neuroradiol 26:2397-2401

31 Fadili Hassani S, Cormier E, Shotar E et al (2018) Intracardiac cement embolism during percutaneous vertebroplasty: incidence, risk factors and clinical management. Eur Radiol. 10.1007/s00330-018-5647-0 
32 Tsai YD, Liliang PC, Chen HJ, Lu K, Liang CL, Wang KW (2010) Anterior spinal artery syndrome following vertebroplasty: a case report. Spine (Phila Pa 1976) 35:E134-136

33 Scroop R, Eskridge J, Britz GW (2002) Paradoxical cerebral arterial embolization of cement during intraoperative vertebroplasty: case report. AJNR Am J Neuroradiol 23:868-870

34 Marden FA, Putman CM (2008) Cement-embolic stroke associated with vertebroplasty. AJNR Am J Neuroradiol 29:1986-1988

35 Beji H, Jr., Menassel B, Sadoune K, Mavrovi E, Pilleul F, Mastier C (2017) A Rare Complication of Percutaneous Transoral Vertebroplasty at C2: Cement Leakage within the Vertebral Artery. J Vasc Interv Radiol 28:1302-1304

36 McGraw JK, Heatwole EV, Strnad BT, Silber JS, Patzilk SB, Boorstein JM (2002) Predictive value of intraosseous venography before percutaneous vertebroplasty. J Vasc Interv Radiol 13:149-153

37 De la Garza-Ramos R, Benvenutti-Regato M, Caro-Osorio E (2016) Vertebroplasty and kyphoplasty for cervical spine metastases: a systematic review and meta-analysis. Int J Spine Surg 10:7

38 Nelson DA, Barker ME, Hamlin BH (1997) Thermal effects of acrylic cementation at bone tumour sites. Int J Hyperthermia 13:287-306

39 Cohen M, Zeitoun D, Blanpain S, Brochard C, Lellouche J, Deramond H (2013) Percutaneous vertebroplasty of the C2 body and dens using the anterior oblique ascending transdiscal approach. J Neuroradiol 40:211215 


\section{Tables}

\section{Table 1.}

Patients' demographics/lesions characteristics

\section{Patients' demographics}

Patients (n) 130

Age (years; $m \pm S D$ ) $\quad 56 \pm 15$

Female (n, \%)

$88(67.7)$

Treated vertebrae (n)

176

cVP procedures (n)

140

Treated vertebrae/session $(\mathrm{m} \pm \mathrm{SD})$

\section{Lesion types}

Metastases (n, \%)

from Breast Kc

78 (44.3)

Thyroid Kc

$15(8.5)$

Kidney Kc

$12(6.8)$

Lung Kc

Prostate Kc

$4(2.3)$

Other Kc

$11(6.25)$

Unknown Kc

Haematological malignancies

Lymphoma

Benign osseous lesions

Hemangioma

$\mathrm{ABC}$

Other

Pretreatment imaging work-up available

$\boldsymbol{n}$ indicates number, $\boldsymbol{m}$ : mean, $\boldsymbol{S D}$ : standard deviations, $\boldsymbol{K c}$ : cancer, $\boldsymbol{A B C}$ : aneurysmal bone cyst 
Table 2.

Review of the literature on cervical vertebroplasties/balloon kyphoplasties

\begin{tabular}{|c|c|c|c|c|c|c|c|c|c|c|c|c|}
\hline Study & VP/BKP & $\begin{array}{c}\mathrm{Nb} \\
\text { patients }\end{array}$ & $\begin{array}{c}\mathrm{Nb} \\
\text { vertebrae } \\
\text { treated } \\
\end{array}$ & $\begin{array}{c}\text { Treated } \\
\text { levels }\end{array}$ & Route & $\begin{array}{l}\text { Underlying } \\
\text { lesion }\end{array}$ & $\begin{array}{l}\text { Mortality } \\
\text { rate (\%) }\end{array}$ & $\begin{array}{l}\text { Complication } \\
\text { rate (\%) }\end{array}$ & $\begin{array}{l}\text { Details on } \\
\text { complications }\end{array}$ & $\begin{array}{c}\text { Cement } \\
\text { leakage } \\
\text { rate }\end{array}$ & $\begin{array}{c}\text { Pain } \\
\text { relief } \\
\text { rate (\%) }\end{array}$ & Comment \\
\hline $\begin{array}{c}\text { Mont'Alverne } \\
\text { F (2005) [9] }\end{array}$ & VP & 12 & 12 & C2 & Anterolateral & Metastases & $0 \%$ & $\begin{array}{l}\text { Major: } 8.3 \% \\
\text { minor: } 8.3 \%\end{array}$ & $\begin{array}{l}\text { Ischemic stroke } \\
(n=1), \text { occipital } \\
\text { neuralgia }(n=1)\end{array}$ & $58.3 \%$ & 80 & - \\
\hline $\begin{array}{c}\text { Pflugmacher } \\
\text { R (2006) } \\
\text { [12] }\end{array}$ & $\begin{array}{c}\text { VP } \\
\text { (surgical } \\
\text { dissection) }\end{array}$ & 5 & 12 & C3-C7 & Anterolateral & $\begin{array}{l}\text { Multiple } \\
\text { myeloma }\end{array}$ & $0 \%$ & $0 \%$ & - & $16.7 \%$ & $100 \%$ & - \\
\hline $\begin{array}{l}\text { Mont'Alverne } \\
\text { F (2009) [10] }\end{array}$ & VP & 4 & 5 & $\mathrm{C} 2-\mathrm{C} 4$ & Anterolateral & $\begin{array}{l}\text { Multiple } \\
\text { myeloma }\end{array}$ & $0 \%$ & $0 \%$ & - & $60 \%$ & $100 \%$ & $\begin{array}{c}\text { Tumor } \\
\text { progression in } \\
\text { one patient } \\
\text { (spine } \\
\text { instability) }\end{array}$ \\
\hline $\begin{array}{c}\text { Sun G (2010) } \\
{[11]}\end{array}$ & VP & 10 & 10 & $\mathrm{C} 2$ & $\begin{array}{c}\text { Anterolateral } \\
\text { and } \\
\text { posterolateral }\end{array}$ & Metastases & $0 \%$ & $\begin{array}{l}\text { Major: } 0 \%, \\
\text { minor: } 30 \%\end{array}$ & $\begin{array}{c}\text { Mild } \\
\text { odynophagia }\end{array}$ & $40 \%$ & $100 \%$ & - \\
\hline $\begin{array}{l}\text { Guarnieri G } \\
(2010)[18]\end{array}$ & VP & 10 & 10 & C2-C5 & $\begin{array}{c}\text { Anterolateral } \\
(70 \%) / \text { transoral } \\
(30 \%)\end{array}$ & $\begin{array}{c}\text { Metastases, } \\
\text { haematological } \\
\text { malignancies, } \\
\text { benign osseous } \\
\text { primitive } \\
\text { tumors }\end{array}$ & $0 \%$ & $0 \%$ & - & $0 \%$ & $90 \%$ & - \\
\hline $\begin{array}{c}\text { Masala S } \\
\text { (2011) [8] }\end{array}$ & VP & 62 & 70 & $\begin{array}{l}\text { Any } \\
\text { cervical } \\
\text { level }\end{array}$ & $\begin{array}{c}\text { Anterolateral } \\
(46.8 \%) / \text { transoral } \\
(53.2 \%)\end{array}$ & $\begin{array}{c}\text { Metastases, } \\
\text { haematological } \\
\text { malignancies, } \\
\text { benign osseous } \\
\text { primitive } \\
\text { tumors }\end{array}$ & $0 \%$ & $0 \%$ & - & $2.9 \%$ & $96.8 \%$ & - \\
\hline $\begin{array}{l}\text { Blondel B } \\
\text { (2012) [7] }\end{array}$ & BKP & 6 & 6 & $\mathrm{C} 2-\mathrm{C} 5$ & Anterolateral & Metastases & $0 \%$ & $0 \%$ & - & $33.3 \%$ & $100 \%$ & $\begin{array}{l}\text { Anterior screw } \\
\text { fixation in one } \\
\text { patient (16.7\%) }\end{array}$ \\
\hline $\begin{array}{l}\text { Anselmetti } \\
\text { GC (2012) [5] }\end{array}$ & VP & 25 & 25 & $\mathrm{C} 2$ & Transoral & $\begin{array}{c}\text { Metastases, } \\
\text { haematological } \\
\text { malignancies, } \\
\text { benign osseous } \\
\text { primitive } \\
\text { tumors }\end{array}$ & $0 \%$ & $0 \%$ & - & $24 \%$ & $96 \%$ & - \\
\hline $\begin{array}{c}\text { Guo WH } \\
(2012)[16]\end{array}$ & VP & 15 & 15 & C1-C3 & Lateral & $\begin{array}{l}\text { Metastases } \\
\text { and benign } \\
\text { osseous } \\
\text { primitive } \\
\text { tumors }\end{array}$ & $0 \%$ & $0 \%$ & - & $33 \%$ & $\begin{array}{l}\text { Not } \\
\text { detailed. } \\
\text { Pain } \\
\text { relief in } \\
\text { most of } \\
\text { the } \\
\text { patients }\end{array}$ & CT-guidance \\
\hline
\end{tabular}




\begin{tabular}{|c|c|c|c|c|c|c|c|c|c|c|c|c|}
\hline $\begin{array}{c}\text { Jian W } \\
\text { (2013) [19] }\end{array}$ & VP & 8 & 8 & C3-C6 & Anterolateral & Haemangiomas & $0 \%$ & $0 \%$ & - & $25 \%$ & $100 \%$ & - \\
\hline $\begin{array}{c}\text { Sun G (2013) } \\
+[13]\end{array}$ & VP & 13 & 13 & $\mathrm{C} 2$ & Anterolateral & Metastases & $0 \%$ & $\begin{array}{l}\text { Major: } 0 \%, \\
\text { minor: } 30.8 \%\end{array}$ & $\begin{array}{c}\text { Mild } \\
\text { odynophagia }\end{array}$ & $38.5 \%$ & $100 \%$ & - \\
\hline $\begin{array}{c}\text { Chen L } \\
(2014)[20] \\
\end{array}$ & VP & 4 & 5 & $\mathrm{C} 5-\mathrm{C} 7$ & Anterolateral & Metastases & $0 \%$ & $0 \%$ & - & $20 \%$ & $100 \%$ & $\begin{array}{c}18 \mathrm{G} \text { needles } \\
\text { used }\end{array}$ \\
\hline $\begin{array}{l}\text { Kordecki K } \\
\text { (2015) [17] }\end{array}$ & VP & 15 & 15 & $\begin{array}{c}\text { Not } \\
\text { detailed }\end{array}$ & Anterolateral & $\begin{array}{c}\text { Metastases, } \\
\text { haematological } \\
\text { malignancies, } \\
\text { benign osseous } \\
\text { primitive } \\
\text { tumors }\end{array}$ & $0 \%$ & $0 \%$ & - & NA & $100 \%$ & - \\
\hline $\begin{array}{c}\text { Stangenberg } \\
\text { M (2017) } \\
{[14]}\end{array}$ & $\begin{array}{c}\text { VP } \\
\text { (surgical } \\
\text { dissection) }\end{array}$ & 14 & 25 & $\mathrm{C} 2-\mathrm{C} 7$ & $\begin{array}{l}\text { Anterolateral } \\
\text { (surgical } \\
\text { dissection) }\end{array}$ & $\begin{array}{c}\text { Metastases } \\
\text { and } \\
\text { haematological } \\
\text { malignancies }\end{array}$ & $0 \%$ & $0 \%$ & - & $8 \%$ & $100 \%$ & $\begin{array}{c}\text { Additional } \\
\text { screw fixation } \\
\text { in } 28.6 \% ; \\
\text { transarticular } \\
\text { C1-C2 fusion in } \\
\text { one case } \\
\end{array}$ \\
\hline $\begin{array}{c}\text { Bao L (2017) } \\
{[6]}\end{array}$ & VP & 9 & 22 & $\mathrm{C} 2-\mathrm{C} 7$ & Anterolateral & Metastases & $0 \%$ & $\begin{array}{l}\text { Major: } 0 \% \\
\text { minor: } 55.6 \%\end{array}$ & $\begin{array}{l}2 \text { patients with } \\
\text { arms numbness, } \\
3 \text { mild } \\
\text { odynophagias }\end{array}$ & $63.6 \%$ & $100 \%$ & $\begin{array}{c}\text { One died from } \\
\text { cervical } \\
\text { paraplegia at } 4 \\
\text { months }\end{array}$ \\
\hline $\begin{array}{c}\text { Sebaaly A } \\
\text { (2018) [15] }\end{array}$ & BKP & 11 & 15 & $\begin{array}{c}\text { Not } \\
\text { detailed; } \\
\text { mainly } \\
\text { C2 }\end{array}$ & Anterolateral & $\begin{array}{c}\text { Metastases } \\
\text { and } \\
\text { haematological } \\
\text { malignancies }\end{array}$ & $9 \%$ & Major: 18\% & $\begin{array}{c}1 \text { pulmonary } \\
\text { embolism; } 1 \\
\text { pulmonary } \\
\text { decompensation } \\
\text { leading to death }\end{array}$ & NA & $82 \%$ & - \\
\hline $\begin{array}{l}\text { Present } \\
\text { study }\end{array}$ & VP & 130 & 176 & $\begin{array}{l}\text { Any } \\
\text { cervical } \\
\text { level }\end{array}$ & $\begin{array}{c}\text { Anterolateral } \\
(96.7 \%) / \text { transoral } \\
(3.3 \%)\end{array}$ & $\begin{array}{c}\text { Metastases, } \\
\text { haematological } \\
\text { malignancies, } \\
\text { benign osseous } \\
\text { primitive } \\
\text { tumors }\end{array}$ & $0.7 \%$ & $\begin{array}{l}\text { Major: } 1.5 \% \\
\text { minor: } 1.5 \%\end{array}$ & $\begin{array}{c}1 \text { death, } 1 \\
\text { compressive } \\
\text { hematoma, } 2 \\
\text { minor } \\
\text { hematomas }\end{array}$ & $61 \%$ & $75.4 \%$ & $\begin{array}{l}6.1 \% \text { of the } \\
\text { patients } \\
\text { required an } \\
\text { additional } \\
\text { fixation surgery }\end{array}$ \\
\hline
\end{tabular}

VP indicates vertebroplasty, VP: vertebroplasty, BKP: balloon kyphoplasty, Nb: number, NA: not available. † probable overlap with the series of Sun G (2010) [11]. 


\section{Figure captions:}

\section{Figure 1.}

Photographs of the different steps in a cVP. A and B. Positioning of the bone needle through a percutaneous route, via an anterolateral approach. $\mathbf{C}$. Connection to the bone needle of the syringe filled with PMMA bone cement, before injection. D. Local compression after the bone needle withdrawal, for a couple of minutes, to avoid the risk of local hematoma. E. Photograph at the end of the procedure, showing the tiny penetration point of the bone needle.

\section{Figure 2.}

cVP in a 40-y-o female with a painful C4 metastatic lesion from a breast cancer. A. Unenhanced CT-scan showing the osteolytic lesion of the C4 vertebra's body (arrow). B. Plain X-Ray, anteroposterior (AP) projection after the positioning of the bone needle via a right anterolateral approach. C. and D. Post-procedure plain X-Ray after cement injection in AP (C) and lateral (D) projections showing a satisfactory filling of the C4 lesions. Note a small posterior non-symptomatic posterior cement leakage (white arrow). E. Post-procedure unenhanced CT acquisition; axial slice in bone windowing confirming the satisfactory filling the lesion and the small posterior cement leakage (white arrow).

\section{Figure 3.}

PRISMA flow chart.

Builder search:

For PubMed, the search was organized as follows:

(("vertebroplasty"[MeSH Terms] OR "vertebroplasty"[All Fields] OR "kyphoplasty"[All Fields]) AND ("neck"[MeSH Terms] OR "neck"[All Fields] OR "cervical"[All Fields])) OR (("vertebroplasty"[MeSH Terms] OR "vertebroplasty"[All Fields]) AND ("axis, cervical vertebra"[MeSH Terms] OR "axis"[All Fields] OR "cervical vertebra axis"[All Fields] OR "C2"[All Fields])) OR (("vertebroplasty"[MeSH Terms] OR "vertebroplasty"[All Fields]) AND "C2"[All Fields]) OR (("vertebroplasty"[MeSH Terms] OR "vertebroplasty"[All Fields]) AND "atlas"[All Fields]) OR (("vertebroplasty"[MeSH Terms] OR "vertebroplasty"[All Fields]) AND “C1"[All Fields]) AND "1950/01/01"[PDAT] : "2019/01/01"[PDAT]

For the Cochrane library, the search was organized as follows:

'vertebroplasty' AND 'cervical' OR 'cementoplasty' 


\section{Figure 4.}

Pie chart summarizing the underlying lesions of the patients included in this series.

\section{Figure 5.}

Pie chart showing the distribution of the cervical vertebrae treated in this study.

\section{Figure 6.}

C2 vertebroplasty in a 68-y-o female presenting an osteolytic lesion of the axis from a breast cancer. The patient still presented severe cervical pain (VAS $=10$ ) despite a previous occipito-cervical fixation. A. and B. Unenhanced CT-scan; coronal (A) and sagittal (B) reconstructions displaying the osteolytic lesion of the axis ( $\mathbf{A}$ and $\mathbf{B}$, arrow). Note the osteolytic lesions involving the C4, C6 and C7 vertebrae (B, arrow heads). cVP was performed under general anesthesia via an anterolateral approach (C: anteroposterior [AP] projection; D: lateral projection). A cone beam CT acquisition was performed to confirm the satisfactory positioning of the bone needle (11G bevelled bone needle, Thiebaud) (E). $2 \mathrm{ml}$ of PMMA bone cement (Biomet V) were injected in both the C2's dens and vertebral body (F: post-cVP plain X-ray in lateral projection). 